\title{
The flexural lumber properties of Pinus patula Schiede ex Schltdl. \& Cham. improve with decreasing initial tree spacing
}

\author{
Justin Erasmus ${ }^{1} \cdot$ David M. Drew $^{1} \cdot$ C. Brand Wessels ${ }^{1}$ \\ Received: 18 April 2019 / Accepted: 11 June 2020 / Published online: 22 July 2020 \\ (C) INRAE and Springer-Verlag France SAS, part of Springer Nature 2020
}

\begin{abstract}
- Key message An increase in the stiffness of lumber with a decrease in initial tree spacing was confirmed for Pinus patula Schiede ex Schltdl. \& Cham. The underlying properties of microfibril angle, wood density and knot frequency explained $\mathbf{7 1 \%}$ of the variation in lumber stiffness. Tree spacing also influenced wood properties independent of radial growth rate. - Context Rapid growth rates and reduced harvesting ages of South African-grown pine plantations have caused a reduction in the stiffness of structural lumber, which accounts for about $75 \%$ of all sawn wood. Microfibril angle and wood density are known to influence wood stiffness, which may be manipulated by the growing space of trees.

- Aims The objective of this study was to evaluate the effect of slower growth rates, caused by narrow tree spacing, on the suitability of Pinus patula Schiede ex Schltdl. \& Cham. wood for structural lumber.

- Methods An 18- and a 19-year-old spacing experiment with four levels of initial tree spacing $(1.83 \mathrm{~m} \times 1.83 \mathrm{~m}, 2.35 \mathrm{~m} \times 2.35$ $\mathrm{m}, 3.02 \mathrm{~m} \times 3.02 \mathrm{~m}$ and $4.98 \mathrm{~m} \times 4.98 \mathrm{~m}$ ) were sampled. Linear and non-linear mixed-effects models were developed to examine the effect of tree spacing on the quality of wood and lumber as defined by the modulus of elasticity, modulus of rupture and knot frequency of 208 boards and the ring-level microfibril angle and wood density of 86 radial strips.

- Results Wood and lumber quality improved with decreasing spacing, and only the narrowest spacing had lumber that conformed to the requirements of the lowest South African structural grade. Microfibril angle, wood density and knot frequency explained $71 \%$ of the variation of lumber stiffness. After accounting for ring width differences, there remained a significant effect of initial spacing on the parameters of models predicting microfibril angle and wood density.

- Conclusion Wide initial spacing is discouraged if higher strength grades are desired for Pinus patula lumber.
\end{abstract}

Keywords Wood quality, $\cdot$ Initial spacing, $\cdot$ Modulus of elasticity, $\cdot$ Microfibril angle, $\cdot$ Wood density

\section{Introduction}

The selection of appropriate spacing between trees is an important tactical decision made in support of forest

\section{Handling Editor: Alexis Achim (Guest Editor)}

Contributions of the co-authors

Conceptualization: BW, JE. Methodology: all. Experimental work: JE. Formal analysis: JE. Writing - original draft: JE. Writing - review and editing: all. Supervision: BW, DD. Funding acquisition: BW

This article is part of the topical collection on Frontiers in Modelling Future Forest Growth, Yield and Wood Properties

C. Brand Wessels

cbw@sun.ac.za

1 Department of Forest and Wood Science, Stellenbosch University, Paul Sauer Building, Bosman Street, Stellenbosch 7599, South Africa management strategies. The resulting growing space available is one of the major factors influencing full realization of the genetic potential of trees, in terms of volume growth (Zobel and Talbert 1984). The delayed onset of competition, caused by sufficient growing space, positively influences tree growth and vigour, which results in greater stem taper, lower living crowns with larger branch sizes and a reduced risk of mortality (Savill et al. 1997; Harrington et al. 2009; Gadow and Kotze 2014; Ashton and Kelty 2018). Tree spacing is also the most powerful management tool available to influence the physical properties of wood raw material and their within-tree variability (Larson et al. 2001; Macdonald and Hubert 2002; Schimleck et al. 2018). Control over tree spacing may be exercised at stand establishment/regeneration (initial spacing) or throughout the rotation at various developmental stages of the stand through respacing (pre-commercial) or thinning (Cameron 2002). 
Globally, the commercial management of softwood plantations has generally moved towards regimes that secure larger volume growth in the shortest possible time, typically favouring wider tree spacing (Hein et al. 2007; Kotze and du Toit 2012; West 2014). This strategic adaptation towards optimized stand volume productivity is guided by management objectives, which classically aim to grow large trees at the lowest cost possible while maximizing financial return. In South Africa, constraints in the form of land availability, water use legislation and conservation demands pose further challenges (Zwolinski and Bayley 2001; Louw 2006). These factors have made South African forestry highly productive (ranked 19th in the world by industrial roundwood production by 2012) despite a forest cover of only about 1.2 million ha (Jürgensen et al. 2014). Between the years 1960 and 2016, plantation production increased by $38 \%$ while the afforested area simultaneously increased by only $5 \%$ (Godsmark 2017). Under such aggressive management, trees consequently grow much faster, and merchantable volumes are realized sooner.

Considering the age dependency of mechanical properties, the main consequence of increased productivity on wood quality is largely considered to be an increase in juvenile wood proportions at final harvest (Larson et al. 2001; Malan 2010). This wood type is characterized by high microfibril angle (MFA) and low wood density (WD) (Moore and Cown 2017), which negatively influences wood stiffness (Cave and Walker 1994; Burdon et al. 2004; Xu and Walker 2004; Vikram et al. 2011; Wessels et al. 2015a). Wood products processed mostly from this type of raw material will likely decrease the percentage of lumber graded to higher strength classes, which are normally classified according to stiffness. Several studies over the last few decades have confirmed the negative effects of increased juvenile proportions on lumber strength (modulus of rupture, MOR) and stiffness (modulus of elasticity, MOE) and in some cases lumber distortion (Kretschmann and Bendtsen 1992; Burdzik 2004; Biblis 2006; Dahlen et al. 2012; Dowse and Wessels 2013). The MOE of some structural lumber produced in South Africa has been reported at $25 \%$ less than the lowest structural grade S5 (Dowse and Wessels 2013) which, in terms of MOE, is comparable to the second lowest European strength class C16 (CEN 2016).

In response to wood quality concerns, initial research in South Africa focussed on establishing the current resource characteristics and variation of mechanical and physical properties of wood, as well as the non-destructive prediction thereof (Wessels et al. 2011, 2014, 2015b, a; Dowse and Wessels 2013; Muller et al. 2017). Much like international research (Moore and Cown 2017; Schimleck et al. 2018), these studies clearly indicate that the nature of wood material from modern plantations has changed and that certain forest management interventions should be considered in order to improve wood quality - particularly stiffness properties. The focus thus shifted towards understanding wood property variation in response to silviculture (Malan 2012), particularly initial spacing (Wessels and Froneman 2015; Erasmus et al. 2018; Froneman and Wessels 2018), with increased emphasis on an end product perspective. These studies provided some evidence that lumber stiffness may indeed be increased through closer tree spacing but that the mediatory mechanisms, such as tree slenderness (Waghorn and Watt 2013), were not consistent with reference species such as Pinus radiata D. Don. The magnitude of positive spacing effects was also species specific. Additionally, Auty et al. (2017) illustrated that models, even with ring width terms, may not be able to fully explain the effects of tree spacing on radial wood property variation. This is an important consideration which, to our knowledge, has only been investigated at one site in the country (Erasmus et al. 2018). More work is therefore required to elucidate and generalize the influence of spacing and its casual factors on wood properties.

An initial experiment evaluating the effect of initial spacing on the MFA and WD of Pinus patula Schiede ex Schltdl. \& Cham. wood was completed, using increment cores from standing trees (non-destructive) of a spacing trial, and was reported by Erasmus et al. (2018). In the current study, an additional spacing trial provided more increment cores but was also destructively sampled and processed into sawn lumber. Data from both spacing trials were utilized in the current study where the objective was threefold: first, to investigate the effect of initial spacing on the physical and mechanical lumber properties of $P$. patula, particularly lumber MOE; second, to assess the influence of MFA, WD and knot properties on lumber MOE; third, to examine the effects of changes in radial growth rate, as mediated through initial spacing, on the within-tree variation of MFA and WD. The results of this study would assist in formulating forest management regimes that consider wood quality of $P$. patula in addition to growth and yield, since this species is the dominant conifer in South Africa and accounts for about half the softwood area in the country (DAFF 2017).

\section{Material and methods}

\subsection{Experimental site and design}

This study was conducted in an 18- and a 19-year-old $P$. patula spacing experiment, both located in the Mpumalanga escarpment near the town of Barberton, South Africa $\left(25.7175^{\circ} \mathrm{S}, 30.9750^{\circ} \mathrm{E}\right.$ and $25.7665^{\circ} \mathrm{S}, 31.2395^{\circ} \mathrm{E}$, respectively). The 18-year-old (Montrose Plantation) experimental trial, reported in the previous study (Erasmus et al. 2018), is situated roughly $30 \mathrm{~km}$ from the 19-year-old (Highlands Plantation) experimental trial. The former occupied a site with a characteristic mean annual temperature of 
$16.2^{\circ} \mathrm{C}$, a mean annual precipitation of $887.7 \mathrm{~mm}$ and clay loam soil with average depths of $366 \mathrm{~mm}$. The same values for the latter were $16.5^{\circ} \mathrm{C}, 905.8 \mathrm{~mm}$ and $628 \mathrm{~mm}$, respectively. The seed stock for both sites did not undergo any genetic improvements with respect to wood properties.

All trees in this study were pruned at 5, 7 and 9 years after planting to a height of 2, 3.5 and $5.5 \mathrm{~m}$, respectively. Each spacing experiment followed a randomized complete block design consisting of four square initial spacing levels, each replicated in two blocks (Table 1). For brevity, we hereafter simply refer to each spacing level by the shortest distance between trees, i.e. $1.83 \mathrm{~m}, 2.35 \mathrm{~m}, 3.02 \mathrm{~m}$ and $4.98 \mathrm{~m}$. Each sampling plot had been planted with 49 seedlings in a $7 \times 7$ tree layout (variable area plots), but only the centre 25 trees were considered in the study reported here as the outer trees were considered buffer rows.

Table 1 Summary of measured and calculated variables across tree spacing at the tree, board and ring level for each plantation

\begin{tabular}{|c|c|c|c|c|c|c|}
\hline \multirow[t]{2}{*}{ Description } & & \multicolumn{4}{|c|}{ Spacing (m) } & \multirow{2}{*}{$\begin{array}{l}\text { Limits/ } \\
\text { required }\end{array}$} \\
\hline & & 4.98 & 3.02 & 2.35 & 1.83 & \\
\hline \multirow{10}{*}{$\begin{array}{l}\text { Tree level: } \\
\text { Montrose and Highlands Plantations }\end{array}$} & Planting density (stems $\mathrm{ha}^{-1}$ ) & 403 & 1097 & 1808 & 2981 & \\
\hline & Survival $(\%)$ & 97 & 91 & 75 & 57 & \\
\hline & Basal area $\left(\mathrm{m}^{2} \mathrm{ha}^{-1}\right)$ & 36.3 & 50.2 & 51.3 & 45.3 & \\
\hline & Relative stand density & 6.2 & 10.0 & 10.9 & 10.6 & \\
\hline & Total stem volume $\left(\mathrm{m}^{3} \mathrm{ha}^{-1}\right)$ & 349 & 463 & 471 & 409 & \\
\hline & Mean DBH $(\mathrm{cm})$ & 33.9 & 24.9 & 21.3 & 18.0 & \\
\hline & Mean height (m) & 23.5 & 22.3 & 21.4 & 20.7 & \\
\hline & Mean slenderness & 0.67 & 0.86 & 0.97 & 1.11 & \\
\hline & Top height (m) & 24.6 & 23.8 & 24.0 & 22.8 & \\
\hline & Quadratic mean DBH (cm) & 34.4 & 25.3 & 21.9 & 18.4 & \\
\hline \multirow{5}{*}{$\begin{array}{l}\text { Tree level: } \\
\text { Highlands Plantation }\end{array}$} & Mean live crown height (m) & 15.2 & 17.9 & 18.0 & 17.0 & \\
\hline & Mean live crown length ratio & 0.37 & 0.26 & 0.21 & 0.27 & \\
\hline & Mean crown mass $(\mathrm{kg})$ & 399 & 102 & 115 & 38 & \\
\hline & Mean branch diameter (mm) & 26.2 & 20.3 & 21.4 & 16.2 & \\
\hline & Mean branch count & 278 & 176 & 112 & 156 & \\
\hline \multirow{14}{*}{$\begin{array}{l}\text { Board level: } \\
\text { Highlands Plantation** }\end{array}$} & Sample size $(\operatorname{logs})$ & 11 & 12 & 12 & 11 & \\
\hline & Sample size (boards) & 74 & 56 & 39 & 39 & \\
\hline & Mean MOE (MPa) & 6503 & 7613 & 7119 & 8537 & 7800 \\
\hline & 5th perc. $\mathrm{MOE}(\mathrm{MPa})$ & 4087 & 4923 & 5129 & 5342 & 4630 \\
\hline & 5th perc. MOR (MPa) & 13.04 & 15.7 & 16.6 & 22.2 & 11.5 \\
\hline & Mean knot frequency & 7.1 & 7.9 & 8.3 & 9.1 & \\
\hline & Mean max knot size (mm) & 14.6 & 10.6 & 11.7 & 7.4 & \\
\hline & $\mathrm{WD}\left(\mathrm{kg} \mathrm{m}^{-3}\right)$ & 445 & 464 & 447 & 467 & 360 \\
\hline & Bow $\left(\mathrm{mm} \mathrm{m}^{-1}\right)$ & 1.88 & 1.75 & 1.95 & 1.36 & 10 \\
\hline & Twist $\left(^{\circ}\right)$ & 2.08 & 2.84 & 3.28 & 3.46 & 5 \\
\hline & Spring (mm) & 1.74 & 2.5 & 2.64 & 1.69 & 15 \\
\hline & $\begin{array}{l}\text { Mean RW } \\
\text { SilviScan (mm) }\end{array}$ & 11.5 & 8.8 & 8.7 & 6.4 & \\
\hline & $\begin{array}{l}\text { Mean MFA } \\
\text { SilviScan }\left({ }^{\circ}\right)\end{array}$ & 21.9 & 16.2 & 16.9 & 14.1 & \\
\hline & $\begin{array}{l}\text { Mean WD } \\
\text { SilviScan }\left(\mathrm{kg} \mathrm{m}^{-3}\right)\end{array}$ & 418 & 458 & 460 & 491 & \\
\hline \multirow{5}{*}{$\begin{array}{l}\text { Ring level: } \\
\text { Montrose and Highlands Plantations }\end{array}$} & Sample size (trees/radial strips) & 20 & 22 & 22 & 20 & \\
\hline & RW (mm) & 9.4 & 6.8 & 6.0 & 5.5 & \\
\hline & $\operatorname{MFA}\left({ }^{\circ}\right)$ & 18.5 & 13.6 & 13.1 & 12.4 & \\
\hline & $\mathrm{WD}\left(\mathrm{kg} \mathrm{m}^{-3}\right)$ & 443 & 491 & 502 & 507 & \\
\hline & LWP $(\%)$ & 26.2 & 31.5 & 31.0 & 32.4 & \\
\hline
\end{tabular}

*Limits and required values according to SANS 1783-2 (2013) and SANS 10163-1 (2003), respectively

**The board-level values for the Highlands Plantation included board position 3 


\subsection{Sampling and measurements}

Relative stand density, a measure of site occupancy, was calculated according to Curtis (1982), and the diameter at breast height (DBH) and standing tree height were manually recorded for all trees (Erasmus et al. 2020). The top height was calculated as the mean height of the $20 \%$ thickest trees per spacing treatment (Sharma et al. 2002). The slenderness of a tree was taken as the ratio of tree height (adjusted by $-1.3 \mathrm{~m}$ in order to coincide with the breast height) to DBH.

Additional data of the Highlands Plantation was available, measured or calculated. This included the measurements of DBH and height for each year throughout the duration of the experiment. A regression-supported sampling was also used to estimate the total mass of the branches of three to four randomly selected trees per spacing treatment. A minimum of 23 branches (one random branch per whorl), distributed over the full length of the bole, were weighed on a green basis (branch wood, bark and foliage combined). The basal diameter was measured on all branches for these trees (2611 branches in total). The logarithmic form of the power law model, with branch basal diameter as the independent variable, was used to estimate model coefficients and then predict branch mass for all branches not weighed, according to the method described by Seifert and Seifert (2014). Dead branches were measured and estimated separately. Crown mass was calculated as the total branch biomass (Table 1). The height of the live crown base was measured, and the ratio of live crown length to the tree height was calculated (four to fifteen trees per treatment). The varying sample size here was due to undistinguishable live crowns caused by fire damage to some branches.

\subsection{Material preparation and testing}

Radial strips were processed from samples removed at $1.3 \mathrm{~m}$ above ground for randomly selected trees of both Plantations for the measurements of MFA and WD using the CSIRO SilviScan 3 apparatus (Evans 1999) in Melbourne, Australia, at a radial resolution of $2 \mathrm{~mm}$ and $0.025 \mathrm{~mm}$, respectively (Table 1). Note that these WD values reported in this study need to be multiplied by 0.8 to approximate basic density. Where possible, compression wood was avoided when processing strips. Latewood percentage (LWP) was calculated using a threshold of $500 \mathrm{~kg} \mathrm{~m}^{-3}$, adjusted according to darker latewood bands of rings.

For the Highlands Plantation only, 11-12 trees per spacing treatment were randomly selected and a $2.4-\mathrm{m}$ saw $\log$ was removed directly above a height of $1.3 \mathrm{~m}$ for each tree (Table 1). The logs were processed using a cant sawing pattern, yielding 208 boards. All boards had a cross-sectional thickness of $38 \mathrm{~mm}$ (wet dimension, $40 \mathrm{~mm}$ ) and a width of either $114 \mathrm{~mm}$ (wet dimension, $120 \mathrm{~mm}$ ) or $152 \mathrm{~mm}$ (wet dimension, $160 \mathrm{~mm}$ ) for logs with larger diameters (Fig. 1). Boards were

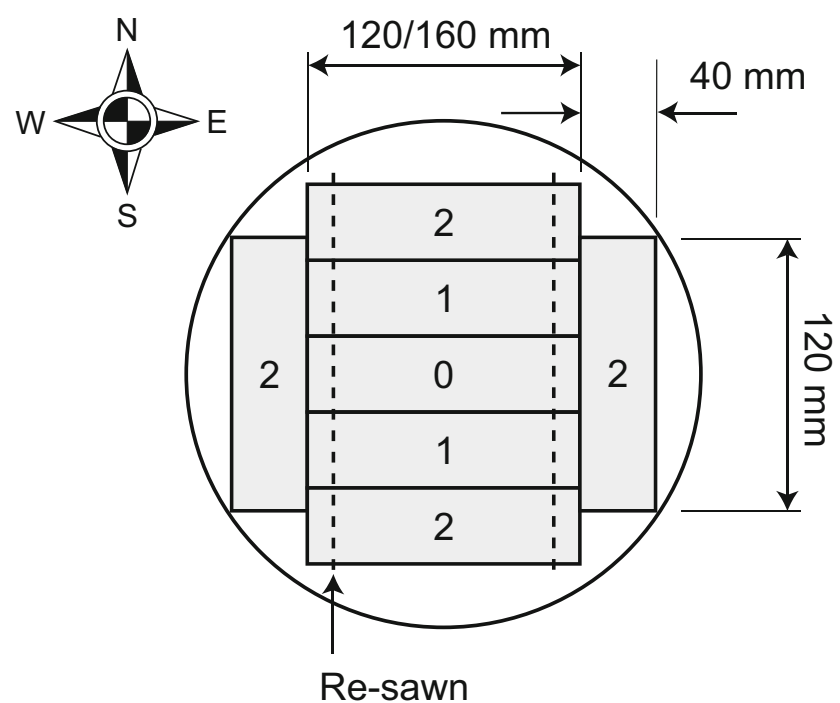

Fig. 1 The sawing pattern used to process logs into boards of the given wet dimensions. Board positions are indicated from 0 (pith board) to 2 (outer board). The dotted lines indicate where the cant boards were resawn to a width of $120 \mathrm{~mm}$ (wet dimensions)

kiln-dried to a target moisture content of $12 \%$. The boards with a width of $152 \mathrm{~mm}$ were also re-sawn to a constant width of $114 \mathrm{~mm}$ for all boards in order to have consistent board sizes and avoid a size effect (Fig. 1). Templates on the ends of logs enabled the tracking of each board processed from a given log. The range of rings present in a given board was counted by reconstructing logs using the templates. Therefore, we could assign a mean ring-level MFA and WD value to each board, as well as the change in both MFA $(\triangle \mathrm{MFA})$ and $\mathrm{WD}(\triangle \mathrm{WD})$ from their minimum to maximum values according to the annual rings of the corresponding radial strip. The position of the boards was defined with respect to those with pith tissue which were marked as "board 0"-also referred to as pith boards in this study (Fig. 1). In a number of cases, the pith extended into an additional board 0 . Due to the small sample size, board 3, sawn adjacent to board 2 in the largest trees, was excluded from the statistical analysis that included board position as a fixed effect. WD, moisture content and distortion (twist, bow and spring) of each board were measured according to SANS 1783-1 (2018). According to the guidelines set out in SANS 6122 (2014), 4-point bending tests were performed using an Instron tensile/bending apparatus. The MOE was calculated between the loads 400 and $2200 \mathrm{~N}$. The maximum knot area (on the surface of the lumber) and the total number of knots (knot frequency) in the maximum stressed area, i.e. centre third of the span, were assessed for each board (Table 1).

\subsection{Data analysis}

The R system for statistical computing (R Core Team 2018) was used for all data analysis. The hierarchical structure of the data warranted the application of linear and non-linear mixed- 
effects models, which can handle an unbalanced design (Lindstrom and Bates 1990; Pinheiro and Bates 2000). Following the experimental design, a nested structure was considered for all the random effects $\left(\sim N\left(0, \sigma^{2}\right)\right)$ of plot, tree and board position, before model simplification. The specific parameterization of models and all fixed and random effects were evaluated and justified with chi-square-based likelihood ratio tests and Akaike's information criterion, AIC (Akaike 1974). Heteroscedasticity was modelled as a function of cambial age, while serial correlation was modelled using a firstorder autoregressive correlation structure. More details on these are given by Auty et al. (2013). Multiple comparisons (Fischer's LSD test) between factor-level means of lumber and wood properties were made with a pairwise significance threshold of $\alpha=0.05$. Fit indices $\left(R^{2}\right)$ were calculated on the fixed part of models, as well as after the inclusion of each random effect, according to the equations given by Parresol (1999). Model performance was assessed with the mean absolute error $|E|$ and root mean square error (RMSE). Only full annual rings were considered for data analysis.

The following model was used to analyse the variation of lumber MOE, MOR and WD as caused by spacing treatment and board position from the pith:

$Y_{i j k l}=\mu+\tau_{i}+r_{k}+(\tau r)_{i k}+b_{i j}+\varepsilon_{i j k l}$

where $Y_{i j k l}$ is the MOE, MOR and WD of an individual board; $\mu$ is the grand mean of the response variable; $\tau_{i}$ is the fixed effect of the $i$ th spacing treatment; $r_{k}$ is the fixed effect of the $k$ th board position; $(\pi r)_{i j}$ is the spacing treatment and board position interaction effect; $b_{i j}$ is the random effect at the tree level; and $\varepsilon_{i j k l}$ is the within-group error. The influence of wood properties on lumber MOE (Highlands only) was also evaluated using the following model:

$$
\begin{aligned}
y_{i j k}= & \beta_{0}+b_{i}+b_{i j}+\beta_{1} M F A_{i j k}+\beta_{2} W D_{i j k} \\
& +\beta_{3} \log \left(K_{i j k}\right)+\varepsilon_{i j k}
\end{aligned}
$$

where $y_{i j k}$ is the MOE of lumber; $\beta_{0}, \beta_{1}, \beta_{2}$ and $\beta_{3}$ are parameters to be estimated from the data; $M F A_{i j k}, W D_{i j k}$ and $K_{i j k}$ are the MFA, WD and knot frequency of each board; $b_{i}$ is the random effect of the $i$ th tree; and $b_{i j}$ is the random effect of the $j$ th board position within the $i$ th tree. Sensitivity analysis was done on the fixed part of the model to determine the relative "influence" of each variable on MOE (Pannell 1997). In Eq. (2), each variable was changed, one at a time, from the observed 5th to the 95th percentile while holding the remaining variables constant at their observed means. Thus the absolute change in the dependent variable, $\left|\Delta y_{i j k}\right|$, was calculated and then recorded as a percentage of the sum of all $\left|\Delta y_{i j k}\right|$ to determine the sensitivity of MOE to the particular variable in question.

Various exponential and logistic model parameterizations were screened to determine the most appropriate model for simulating the pith-to-bark behaviour of ring-level MFA and WD. The modified three-parameter logistic model, Eq. (3), presented by Jordan et al. (2005), proved to be the best fit for MFA:

$y_{i j}=\frac{\alpha_{0}}{1+\exp \left(-\alpha_{1} C A_{i j}\right)}+\alpha_{2}+\mathrm{a}_{2, i}+\varepsilon_{i j}$

$y_{i j}=\frac{\alpha_{0}}{1+\exp \left(\left(-\alpha_{1}+\alpha_{3} R W_{i j}\right) C A_{i j}\right)}+\alpha_{2}+\mathrm{a}_{2, i}+\varepsilon_{i j}$

where $y_{i j}, C A_{i j}$ and $\varepsilon_{i j}$ are the MFA, cambial age (ring number from pith) and the residual error of the $j$ th annual ring in the $i$ th tree respectively; $\left(\alpha_{0} / 2+\alpha_{2}\right), \alpha_{1}$ and $\alpha_{2}$ correspond to the initial MFA ( $y$-intercept), the rate parameter and the lower asymptote, respectively, which could all vary with initial spacing, plantation and the interaction between them; and $a_{2, i}$ is the random effect of parameter $\alpha_{2}$ for the $i$ th tree. Since changes in wood properties due to silvicultural events are typically accompanied with responses in the radial growth of trees, we additionally wanted to see if there remained an effect of spacing on model parameters, over and above $C A_{i j}$ and ring width $\left(R W_{i j}\right)$. The $\alpha_{1}$ parameter was therefore changed to a linear function of $R W_{i j}$ (Eq. (4)). As demonstrated by Auty et al. (2013), radial MFA profiles were then simulated (Eq. (4)) by using mean ring width values per annual ring and spacing, which were predicted by Eq. (3) with $R W_{i j}$ as the dependent variable (parameters not shown).

Alternative parameterizations of the same models proved to be the best fit in modelling WD:

$y_{i j}=\frac{\alpha_{0}+\mathrm{a}_{0, i}}{1+\exp \left(-\alpha_{1} C A_{i j}\right)}+\alpha_{2}+\varepsilon_{i j}$

$y_{i j}=\frac{\alpha_{0}+\alpha_{3} R W_{i j}+\mathrm{a}_{0, i}}{1+\exp \left(-\alpha_{1} C A_{i j}\right)}+\alpha_{2}+\varepsilon_{i j}$

where $y_{i j}$ is the WD of the $j$ th annual ring in the $i$ th tree; $\alpha_{0}$ is the maximum (asymptotic) WD value; $\alpha_{1}$ is the rate parameter; and $\left(\alpha_{0} / 2+\alpha_{2}\right)$ is the initial WD value. Equation (5) allows the $\alpha_{0}$ parameter to vary randomly instead, while Eq. (6) adjusts the same parameter for $R W_{i j}$. This had the effect of adjusting the asymptotic mature wood values and increasing the effect of $R W_{i j}$ with $C A_{i j}$. Once again, the fixed parameters could vary with plantation, spacing and their interaction. Slenderness was also added to the models, in place of RW, for both MFA and WD models (Highlands Plantation only), but RW proved to contribute more to the explanation of wood property variation.

\section{Results}

\subsection{Stand characteristics}

Tree survival rates and site occupancy are indicated in Table 1. DBH increased with spacing for all ages. 

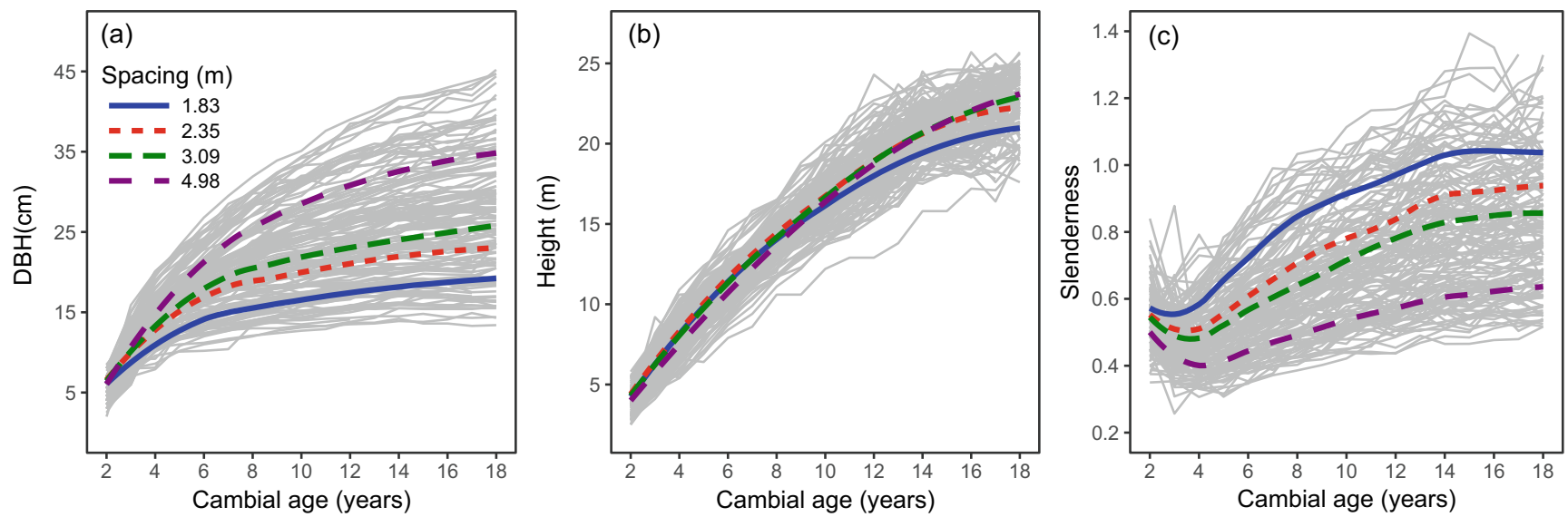

Fig. 2 The variation of (a) DBH, (b) height and (c) slenderness after reaching $1.3 \mathrm{~m}$, for the Highlands Plantation only, fitted with a locally weighted smoothing function to all observations (grey lines) for each spacing

Differences also increased with age, especially between the two widest spacing treatments (Fig. 2a). Tree height remained relatively similar for all ages up until ages of about 10 after which the change in height decreased for $1.83 \mathrm{~m}$ (Fig. 2b). After an initial decrease, slenderness gradually increased and was consistently greater with decreasing spacing (Fig. 2c). The rate of change in slenderness was slightly sharper with closer spacing. Crown development in terms of mass was far greater in the wider spacing (Table 1) due to both larger tree diameters and greater number of branches. Crown size generally reduced with closer spacing (Table 1).

\subsection{Board-level MOE and MOR}

Individual board MOE, which included the extra board position 3, varied from 3766 to $13,601 \mathrm{MPa}$, and the mean MOE increased with closer spacing with the exception of a relatively small decrease from 3.02 to 2.35 $\mathrm{m}$ (Table 1). There were 13 pieces of lumber within board position 3, of which 11 came from the widest spacing. There was a significant linear relationship between MOE and mean CA $\left(R^{2}=0.46 ; p<0.001\right)$. Differences in MOE between board 1 and 2 increased with decreasing spacing (except from 3.02 to $2.35 \mathrm{~m}$, Fig. 3a). MOE for board 2 of the narrowest spacing was significantly greater than that of the $2.35 \mathrm{~m}$ and $3.02 \mathrm{~m}$ spacing, which in turn were significantly greater than that of the widest spacing. The mean MOE for board position 3 in the widest spacing was $7806 \mathrm{MPa}$, which was not considerably higher than that of board position 2 of the same spacing- $7619 \mathrm{MPa}$. MOE for board 2 of the widest spacing displayed no significant difference to that of board 1 of $2.35 \mathrm{~m}$ spacing, and even with board 0 for the closest spacing. Only board 2 for a spacing of $3.02 \mathrm{~m}$ and closer had mean values greater than 7800 $\mathrm{MPa}$, and consequently, only the $1.83 \mathrm{~m}$ spacing conformed to the S5 mean MOE standard (Table 1). The widest spacing was the only treatment that failed to fulfil the required fifth percentile MOE (Table 1). MOE variation could be moderately explained by both the mean MFA $\left(R^{2}=0.58 ; p<0.001\right)$ and WD of lumber $\left(R^{2}=0.53 ; p<0.001\right)$ individually. However, WD had the greatest effect on MOE in the model given by Eq. (2), followed by knot frequency and lastly mean MFA (Table 2). The model was able to explain $71 \%$ of the variation in MOE ( $92 \%$ with random effects) (Table 3).

MOR varied from 9 to $86.3 \mathrm{MPa}$ and was best explained by MOE $\left(R^{2}=0.73\right)$. Therefore, the variation of MOR across spacing and board position generally followed the same patterns as MOE. MOR for the outermost boards of the closest spacing was significantly greater than the rest (Fig. 3b). Board 2 for the widest spacing displayed no significant difference to board 1 for the second widest spacing and even board 0 of the two narrowest spacings. Overall, the fifth percentile MOR was sufficient to comply with the characteristic bending strength of grade S5 lumber, and the 2.35 and $1.83 \mathrm{~m}$ spacing treatments even complied with grade $\mathrm{S} 7$ requirements (15.8 MPa).

\subsection{Board-level WD and distortion}

The WD of boards varied from 356 to $638 \mathrm{~kg} \mathrm{~m}^{-3}$ and had a moderate relationship with mean CA $\left(R^{2}=0.53\right)$ and MOE $\left(R^{2}=0.51\right)$ but displayed a weaker relationship with MOR $\left(R^{2}\right.$ $=0.35$ ). Compared with MOE and MOR, a similar pattern of variation of WD is observed (Fig. 3c). Board 2 for the three closest spacing treatments was significantly greater than that of the widest spacing, which was not significantly different to board 1 for the other spacing treatments. All spacing treatments conformed to the $\mathrm{S} 5$ standard for WD at the board level (Table 1). 

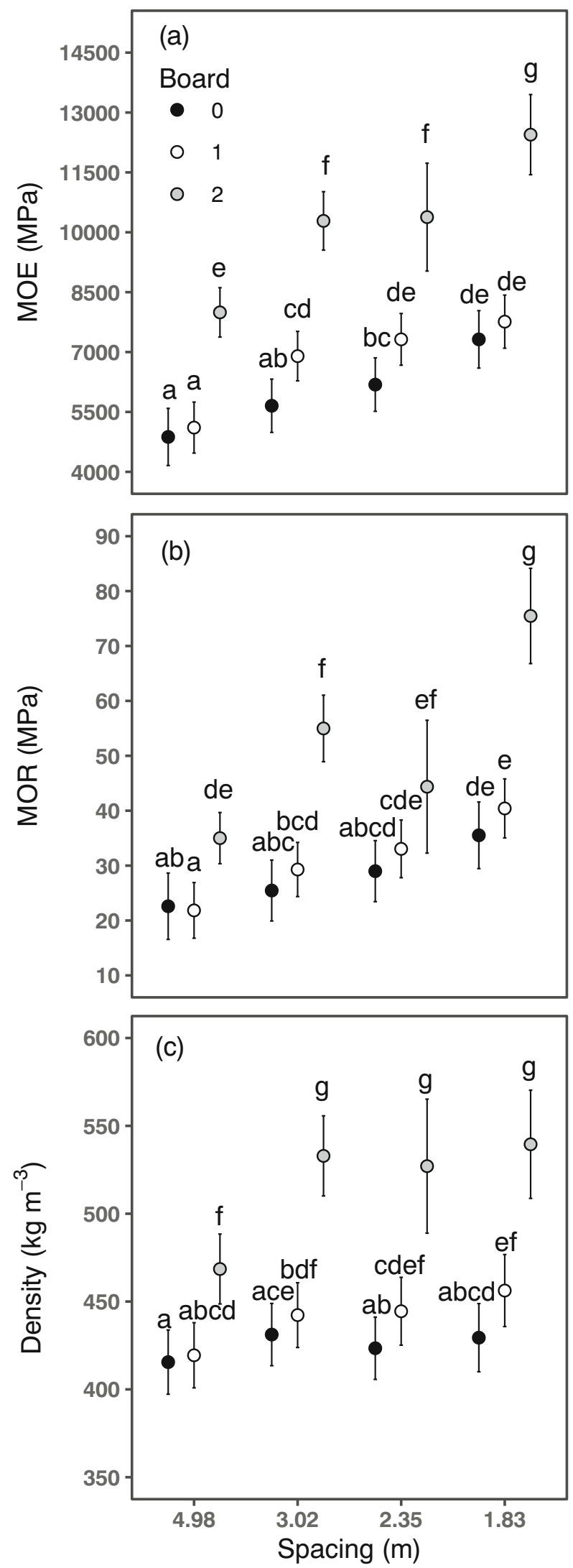

Fig. 3 Means and 95\% confidence intervals of (a) MOE, (b) MOR and (c) WD at different spacing and board position. Different letters denote significant differences
Table 2 Sensitivity analysis of the fixed effects of Eq. (2)

\begin{tabular}{lllllll}
\hline Parameter & Coefficient & \multicolumn{5}{l}{ Sensitivity analysis } \\
\cline { 3 - 7 } Intercept & 3948 & Mean & 5th & 95th & Change & $\%$ \\
\hline WD & 15.4 & 453.8 & 393.3 & 545.0 & 2331.4 & 0.38 \\
MFA & -84.1 & 19.4 & 8.5 & 30.0 & -1805.0 & 0.30 \\
Log (knots) & -994.8 & 2.0 & 1.1 & 3.0 & -1935.8 & 0.32 \\
\hline
\end{tabular}

Spacing had no clear effect on values of bow and spring but twist decreased notably with spacing (Table 1). Twist also consistently decreased from 4.4 to $1.6^{\circ}$ from board 0 to 2 . The relationships between lumber distortion and the mean MFA, $\triangle$ MFA and $\triangle$ WD respectively, were all very weak and below $R^{2}=0.03$. Overall, the mean lumber distortion values in this study were lower than the limits for structural use (Table 1).

\subsection{Ring-level MFA and WD}

The mean MFA per treatment varied between approximately 8 and $32^{\circ}$, displaying a decreasing non-linear trend with CA (Fig. 4a). MFA for the Montrose Plantation decreased more rapidly compared with Highlands (Fig. 4a). Values for the 4.98-m spacing was, on average, $4.9^{\circ}$ greater than for $3.02 \mathrm{~m}$. Compared with the rest, the $4.98-\mathrm{m}$ spacing clearly exhibited a lower radial MFA gradient which began to stabilize after age 10 , which was roughly three rings more than for any other spacing (Fig. 4b). MFA for the three other spacing treatments were relatively similar at equivalent rings. Results from Eq. (3) confirmed these observations. Both the $\alpha_{0}$ and $\alpha_{2}$ parameters were not significantly influenced by either plantation or spacing, but the $\alpha_{1}$ parameter was significantly lower for the Montrose Plantation. The $\alpha_{1}$ parameter was also significantly greater for the widest spacing (Fig. 5a).

Equation (4) proved to be the best fitting model, explaining $81 \%$ ( $88 \%$ with random effects) of MFA radial variation (Table 3 ). MFA was strongly associated with RW $\left(R^{2}=0.74\right)$. After accounting for differences in RW, there was a significant influence of the interaction between spacing and plantation on the $\alpha_{0}, \alpha_{1}$ and $\alpha_{3}$ parameters (Fig. $5 \mathrm{~b}, \mathrm{c}, \mathrm{d}$ ), which was small in the case of $\alpha_{0}$. The $\alpha_{1}$ parameter was still significantly greater for the widest spacing (i.e. a slower radial rate of change), while the coefficient of RW $\left(\alpha_{3}\right)$ was also significantly influenced by spacing, although only for the Montrose Plantation (Fig. 5c, d). The $\alpha_{2}$ parameter was not significantly influenced by any factor. Overall, modelled MFA for the 4.98-m spacing treatment clearly 
Table 3 Summary of all model statistics given by Eqs. (1-6)

\begin{tabular}{|c|c|c|c|c|c|c|c|c|c|}
\hline \multirow[t]{2}{*}{ Level } & \multirow[t]{2}{*}{ Model } & \multirow[t]{2}{*}{ Property } & \multirow[t]{2}{*}{ AIC } & \multirow{2}{*}{$\begin{array}{l}\text { Log- } \\
\text { likelihood }\end{array}$} & \multicolumn{3}{|l|}{$\mathrm{R}^{2}$} & \multicolumn{2}{|c|}{ Model errors } \\
\hline & & & & & Fixed & Tree & Board position & $|E|$ & RMSE \\
\hline \multirow[t]{4}{*}{ Board } & Eq. 1 & MOE & 3101 & -1537 & 0.71 & 0.86 & - & 895 & 1142 \\
\hline & Eq. 2 & MOE & 3310 & -1648 & 0.71 & 0.83 & 0.92 & 867 & 1133 \\
\hline & Eq. 1 & MOR & 1422 & -697 & 0.57 & 0.69 & - & 8 & 10 \\
\hline & Eq. 1 & WD & 1777 & -873 & 0.47 & 0.82 & - & 27 & 35 \\
\hline \multirow[t]{4}{*}{ Ring } & Eq. 3 & MFA & 5251 & -2532 & 0.78 & 0.85 & - & 3.0 & 4.0 \\
\hline & Eq. 4 & MFA & 5067 & -2421 & 0.81 & 0.88 & - & 2.8 & 3.7 \\
\hline & Eq. 5 & WD & 12802 & -6374 & 0.50 & 0.75 & - & 52.7 & 69.3 \\
\hline & Eq. 6 & WD & 12737 & -6330 & 0.54 & 0.76 & - & 50.3 & 67.0 \\
\hline
\end{tabular}

displayed the slowest radial rate of decline (Fig. 4c). Up to about CA 10, the second widest spacing was also generally greater than the two closest spacing treatments. When plotting the modelled MFA against tree radius, differences between the widest spacing and the rest increased more markedly due to the combined effects of RW and annual MFA increases with increased spacing (Fig. 4d).

The mean WD per treatment increased steadily from pith to bark, varying roughly between 340 and $580 \mathrm{~kg}$ $\mathrm{m}^{-3}$ (Fig. 6a), and was closely associated with LWP $\left(R^{2}\right.$ $=0.77)$. The Highlands Plantation had a slightly steeper
Fig. 4 Observed radial profiles of MFA for each plantation (a) and spacing level (b) fitted with locally weighted smoothing functions ("loess") to all observations, which are represented by grey lines. The predicted MFA given by Eq. (4), for each spacing treatment in the Highlands Plantation, is indicated in (c) and presented on a radius scale in (d). Grey vertical lines in (d) represent the maximum radial distance (in all directions) bounded by a given board position (see Fig. 1) (a)

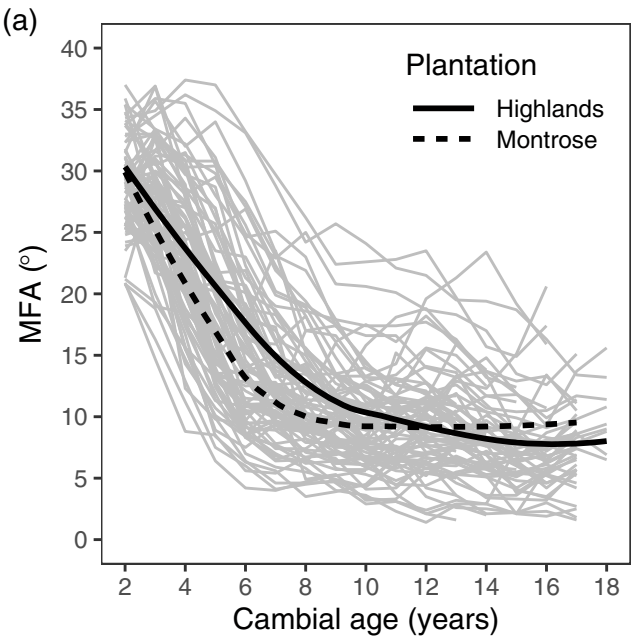

(c)

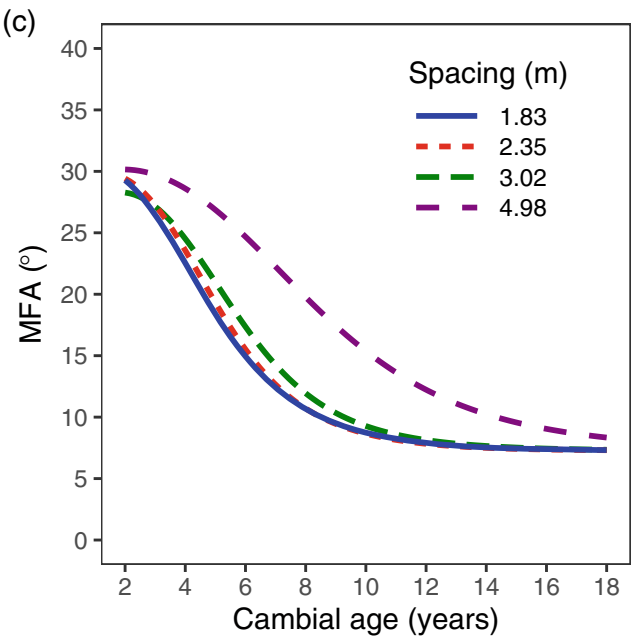

(b)

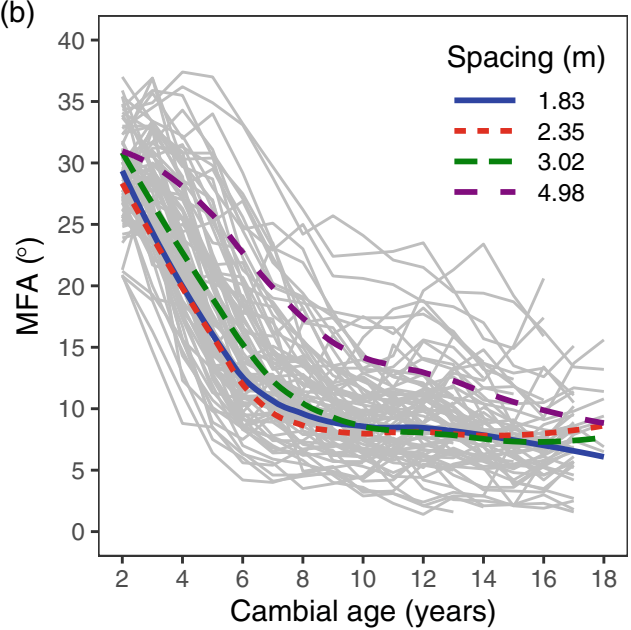

(d)

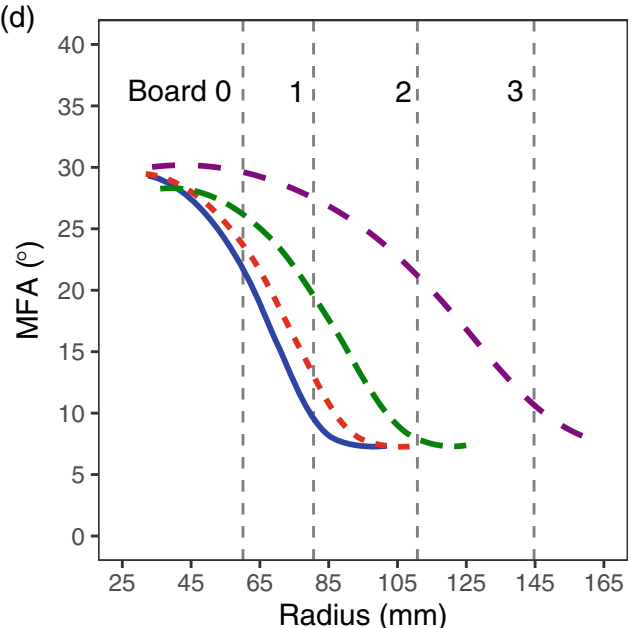


Fig. 5 Parameter estimates and 95\% confidence intervals for the $\alpha_{1}$ parameter of Eq. (3) in (a) and the $\alpha_{0}, \alpha_{1}$ and $\alpha_{3}$ parameters of Eq. (4) in (b), (c) and (d) respectively, for the prediction of MFA. Different letters denote significant differences
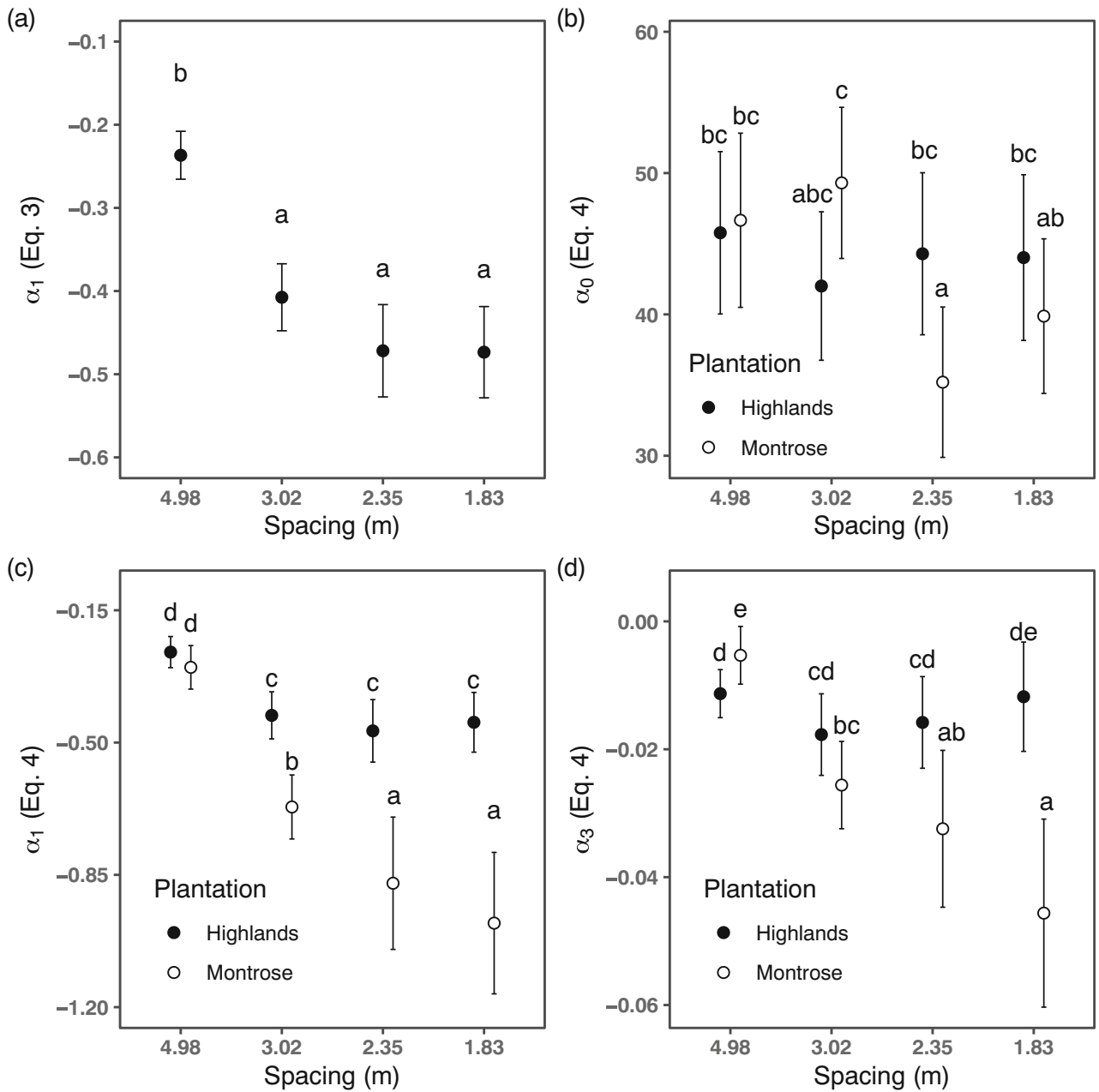

initial incline in WD compared with Montrose (Fig. 6a). WD in the 4.98-m spacing also displayed no clear indication of reaching a stable value towards the bark compared with the other treatments, which began to stabilize at around the 10th annual ring (Fig. 6b). Accordingly, Eq. (5) showed that the Montrose Plantation had both a significantly greater $\alpha_{2}$ parameter, related to the initial value, and a slower radial incline rate for WD $\left(\alpha_{1}\right)$. The widest spacing also had the lowest $\alpha_{0}$ parameter (Fig. 7a). A better depiction of the overall effect of spacing can be seen in Fig. 6c, given by Eq. (6) (explaining $54 \%$ of the variation, Table 3 ), which confirms the main difference being the lower WD gradient for the widest spacing. WD was moderately associated with $\mathrm{RW}\left(R^{2}=\right.$ 0.43). Equation (6) showed that spacing also had a significant effect on model parameters over and above RW (Fig. 7b, c), although the $\alpha_{1}$ parameter was not significantly influenced by any factor. The effect of RW on WD was also significantly influenced by the interaction of spacing and plantation (Fig. 7d). Predicted WD, based on distance from pith, is indicated in Fig. 6d where differences between spacing increased.

\section{Discussion}

\subsection{Influence of initial spacing on grade recovery}

Results of this study contribute clear findings to the body of literature dealing with the generally positive effects of closer spacing on the mechanical properties of lumber processed from several species (Johansson 1992; Brazier and Mobbs 1993; Clark et al. 1994; Moore et al. 2009; Amateis et al. 2013; Rais et al. 2014; Froneman and Wessels 2018; Erasmus and Wessels 2020). For P. patula, it is evident that as initial spacing increases, conformance to minimum structural requirements is limited by lumber MOE. This has also been proven true for South African-grown Pinus radiata (Wessels and Froneman 2015) and Pinus elliottii (Froneman and Wessels 2018). The opposite has been shown for conifers on much longer rotations where the MOR limits the strength class to which lumber may be graded before the MOE does, when increasing tree spacing (Moore et al. 2009). However, results are dependent on stand conditions and are best applicable to corresponding site- and species-specific management regimes. 
Fig. 6 Observed radial profiles of WD for each plantation (a) and spacing level (b) fitted with locally weighted smoothing functions ("loess") to all observations, which are represented by grey lines. The predicted WD given by Eq. (6), for each spacing treatment in the Highlands Plantation, is indicated in (c) and presented on a radius scale in (d). Grey vertical lines in (d) represent the maximum radial distance (in all directions) bounded by a given board position (see Fig. 1)
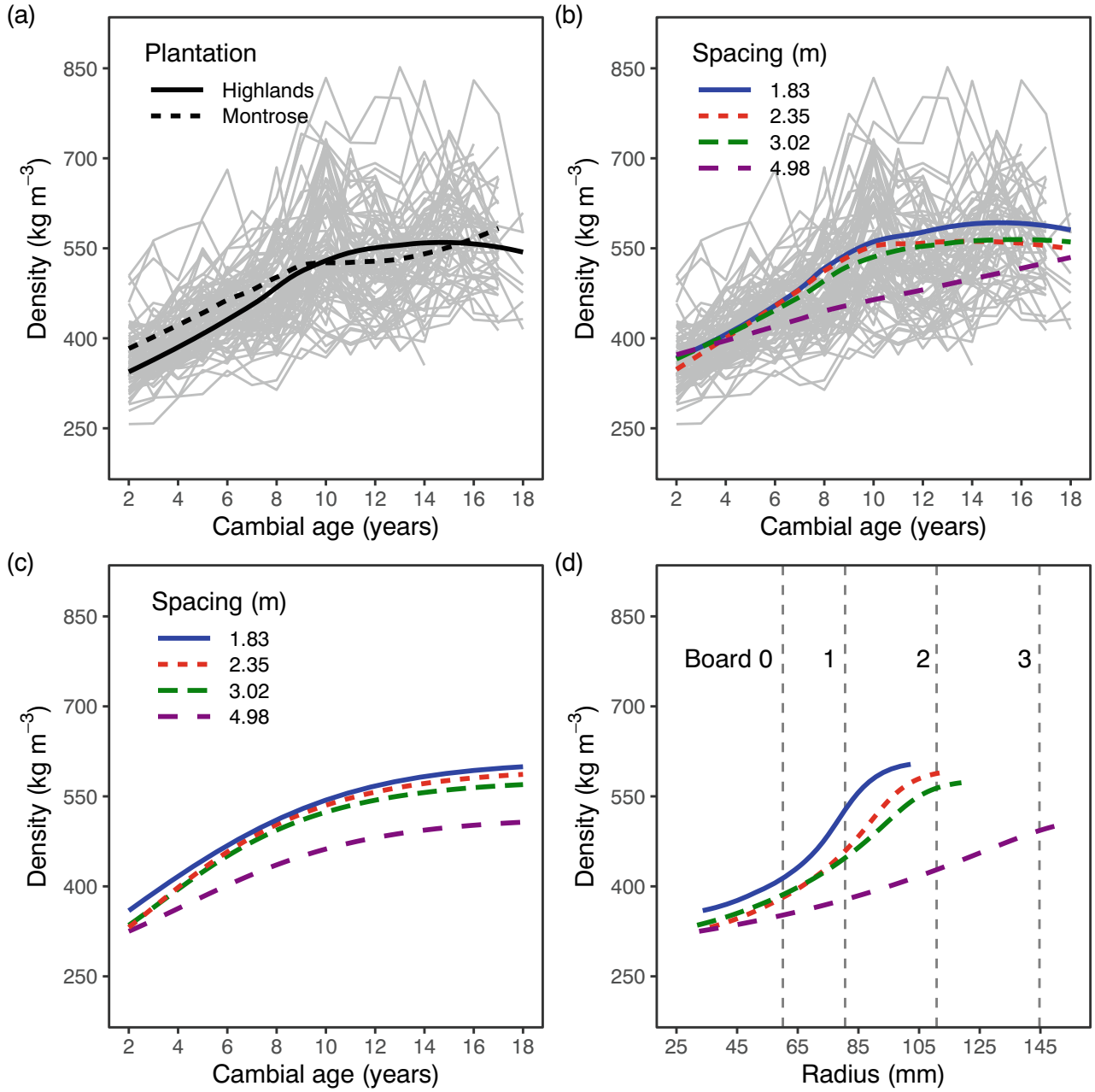

In addition to strength and stiffness, acceptably low levels of lumber distortion are also required by end users which, in the case of twist, has been reported as problematic for $P$. patula resources (Dowse and Wessels 2013; Wessels et al. 2014). The variation of twist in this study was consistent with previous research that reported a reduction in distortion from the juvenile core to the outer mature wood (Brazier and Mobbs 1993; Moore et al. 2009). Although twist increased notably with spacing, its variation was less compared with the aforementioned studies on $P$. patula, which used different spacing ranges.

\subsection{Mechanisms through which initial spacing influences lumber properties}

In this study, we showed that MFA correlated well with MOE and was the best individual predictor thereof, which supports previous studies (Cave and Walker 1994; Walker and Butterfield 1996). This was despite the complexity in determining exactly which rings were present in boards, given that only a single radial strip was used to relate ring-level properties to boards and ignoring circumferential and longitudinal variation. Collectively, however, MOE was slightly more sensitive to knot frequency and especially WD. This result differs somewhat from a previous study on $P$. patula (Wessels et al. 2015a), perhaps due to the lower spacing range, but consistent with other studies using different resources (Downes et al. 2002; Vikram et al. 2011).

Ring-level MFA and WD both displayed a relatively rapid initial gradient, improving favourably from the pith with gradients tending to react more sharply with reduced spacing. This feature has been recognized in previous studies on P. patula (Malan et al. 1997) and other species (Fujimoto and Koga 2010; Watt et al. 2011; Moore et al. 2015). As a result, ring-level properties reach more uniform values at earlier CA. Considering that wood developed prior to this point fulfils the definition of juvenile wood according to Zobel and Sprague (1998), it then follows that the juvenile core is restricted in age with closer spacing. Note that the added effect of plantation on the radial gradient of wood properties implies that a sharp initial decline in MFA in narrow spacing could be similar to that of wider spacing on a different site, i.e. they have the same age of transition from juvenile to mature wood. For a given site, closer spacing also had the effect of improving the average MFA, WD and LWP (Table 1). Furthermore, 
Fig. 7 Parameter estimates and 95\% confidence intervals for the $\alpha_{1}$ parameter of Eq. (5) in (a) and the $\alpha_{0}, \alpha_{2}$ and $\alpha_{3}$ parameters of Eq. (6) in (b), (c) and (d) for the prediction of WD. Different letters denote significant differences.
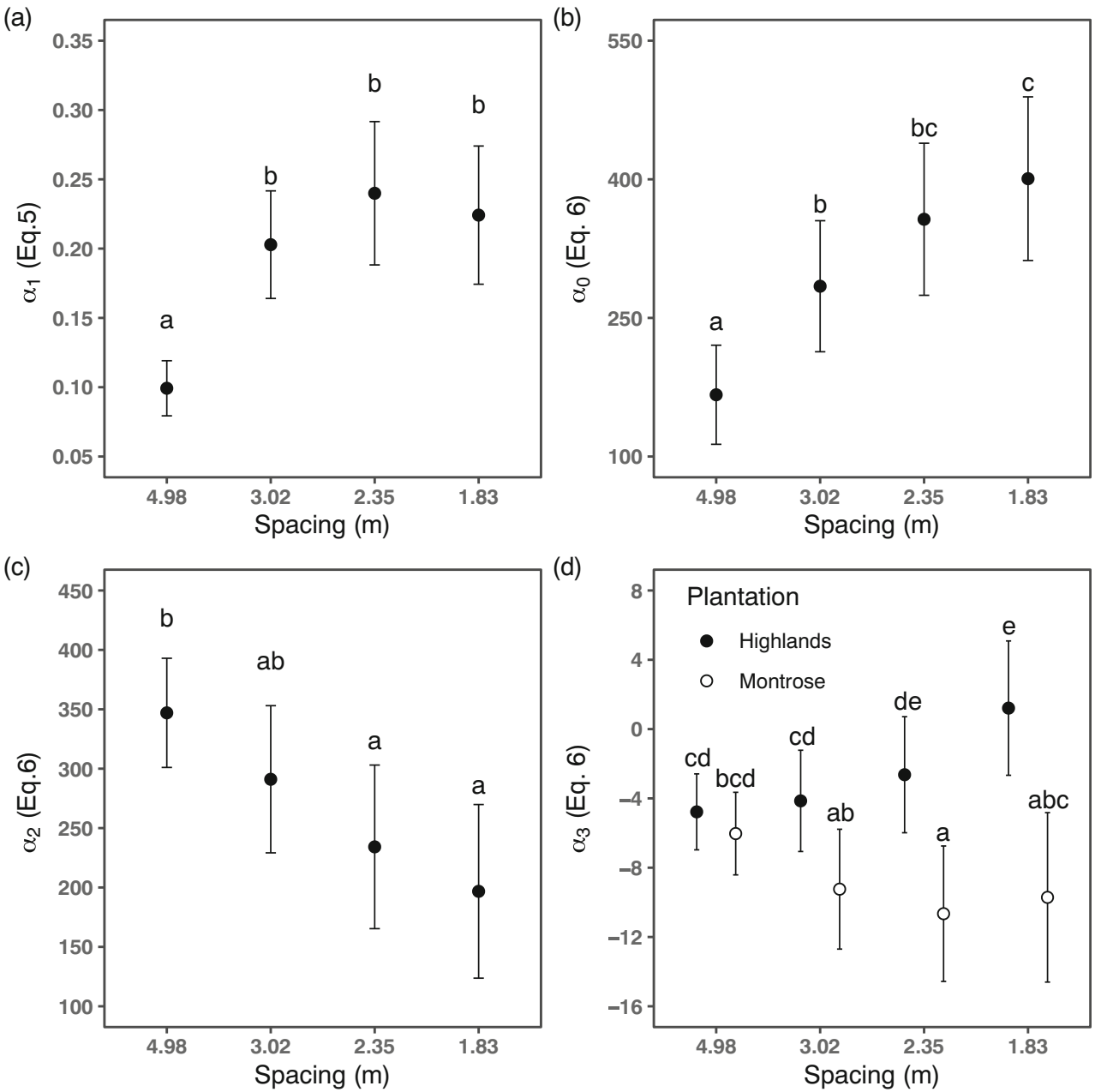

(d)

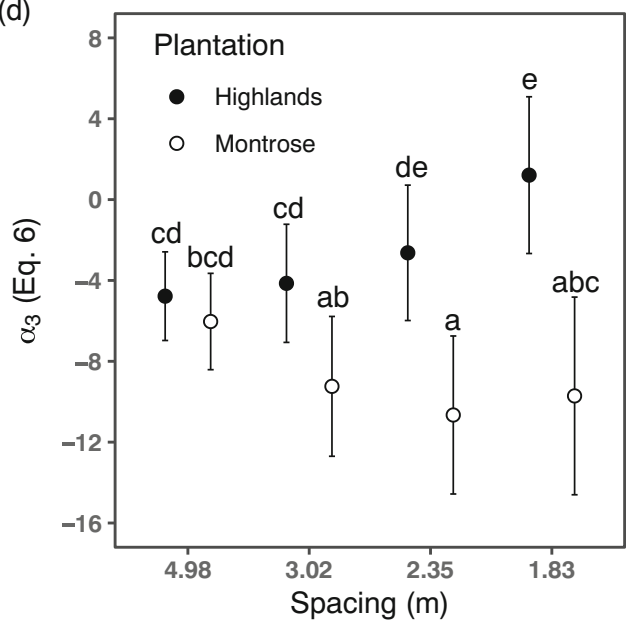

the growth rate is markedly slower closer to the pith for closer spacing (Erasmus et al. 2018) therefore, increasing differences in wood properties between spacing at equivalent radii (Fig. 4 and 6). This observation was also reflected at the board level where the MOE was generally higher at the same board position. The same pattern was observed for MOR, which was unsurprising considering that the two are typically highly correlated (Johansson 2003). Note that the smaller difference between board 0 and 1, compared with the rest, contributes to the explanation of the comparable lumber properties between these board positions (Figs. 4d and 6d). Although the widest spacing produced additional boards (board position 3 ), the overall MOE was still inferior to that of the closer spacing. This can also be seen in the predicted MFA and WD of boards (Figs. $4 \mathrm{~d}$ and $6 \mathrm{~d}$ ). The influence of sawing pattern on the average properties of lumber will ultimately depend on the allocation of rings to a given board position. Nevertheless, if the underlying wood property gradients of wider tree spacing is consistently unfavourable at a given CA, as was the case in our study (Fig. 4c and 6c), then the average mechanical properties of lumber will likely be inferior compared with closer spacing, regardless of sawing pattern.
The increase in differences of wood properties at greater distances from the pith elucidates the significant interaction between spacing and board position on mechanical and physical lumber properties. The practical implications are that the difference in mechanical properties between inner and outer boards are greater for closer spacing which is considered undesirable in terms of processing efficiency (Malan 2010). The uniformity of annual rings within a single piece of lumber is also a priority trait to many sawmills (Hassegawa et al. 2020). Our study showed that individual boards themselves will have sharper MFA and WD gradients in closer spacing, which could lead to uneven shrinkage or distortion (Walker and Nakada 1999; Huang et al. 2003). This occurrence was not evident in the results reported here. However, the fact that the mean twist of boards increased with closer spacing lends some support to this view. Sawing patterns that increase the ring count of wood with sharp MFA gradients may be influential in this regard (Tsoumis 2009). Overall, the magnitude of the increase of twist with spacing in this study is however of little practical importance as it was well within the limits for structural lumber. 


\subsection{Tree developmental effects on wood quality}

With reference to the work reviewed by Zobel and Van Buijtenen (1894), Malan et al. (1997) concluded that the relationship between growth rate and WD is extremely complex given the varying interaction with environment and genetic material. For a given quantity of photosynthetic substances produced by the crown, a fast-growing tree will not always prioritize cell production over cell material (Malan et al. 1997). Furthermore, Larson et al. (2001) argues that the effect of RW on WD is an artefact of the inherent age dependency of WD and that the effect of juvenile growth rate, for a given CA, may be negligible. There was some evidence in this study to partially support this view as ring width differed markedly with spacing while WD remained relatively similar near the pith. However, after accounting for CA, there was an effect of $\mathrm{RW}$, which increased at higher CA. It was also interesting to note that the inclusion of a RW term in Eq. (6) accounted for the differences in the radial rate of change in WD between spacing treatments. However, there was still a significant effect of spacing on the remaining parameters. The residual effect of initial spacing on wood properties in this study also suggests that there are additional causal factors that control differences in wood properties across spacing treatments, which require further investigation. An explanation argued by Auty et al. (2017), with respect to wood density, is that widely spaced trees may tend toward a minimum value regardless of radial growth. From a wood property modelling perspective, it is important to consider the limitations associated with the use of growth rate as a proxy for spacing given that the effects of spacing beyond growth rate are typically considered negligible.

There is consensus between many authors that the rapid initial decline in MFA is associated with mechanical constraints related to tree slenderness (Spatz and Bruechert 2000; Watt et al. 2006; Lachenbruch et al. 2011; Waghorn and Watt 2013; Wessels et al. 2015b). Saplings with small diameters produce higher MFA, which endows trees with considerable flexibility of the stem, acting as a safeguard against external forces. As the tree grows, a decrease in flexibility is beneficial to support its increasing weight. Slenderness in this study did not however contribute more than RW to the explanation of MFA or WD which perhaps, in this case, resulted more from intrinsic gene expression manipulated by other spacing factors rather than extrinsic controls related solely to slenderness (Lachenbruch et al. 2011). Within the first four rings at breast height, both slenderness and MFA decreased; thereafter, slenderness increases. This may represent a possible adaptation to a different developmental stage. Watt and Kirschbaum (2011) argue that part of the reason for slender stems in denser stands are that trees are guarded against excessive sway by neighbouring trees (Milne 1991), reducing the effect of wind in the canopy (Green et al. 1995). Canopy closure also begins earlier for closer spacing (Kotze and du Toit 2012). This allows a tree to secure greater height at a given diameter. Alternative models explaining the decreased MFA and increased stiffness are cell hydraulic aspects and crown development (Domec and Gartner 2002; Kuprevicius et al. 2013; Krajnc et al. 2019). In addition, although the closely spaced trees were much more slender, they had considerably less crown mass to support (Table 1). According to Larson et al. (2001), the sharper radial decline in wood properties with closer spacing is due to a restriction on crown development rather than a direct effect of spacing (see Table 1). On the basis of this view, it is then logical to hypothesize that the differences in the radial property gradients between the plantations reported here are likely due to different site conditions mediated through the developing foliar organs. There may be opposing factors however, since the Montrose Plantation had the steepest MFA gradients, while the Highlands Planation had the steepest WD gradients.

\subsection{Commercial implementation of closer spacing}

From a wood quality perspective, this study in conjunction with many previous investigations seems to encourage management regimes that promote higher stand densities than are currently used commercially. However, there has been limited response from South African and other Southern Hemisphere forest owners to such findings. This could be because forestry planners rarely incorporate the financial effect of betterquality lumber in their planning scenarios and that very little work has been performed to quantify the economic benefits of such management scenarios for the full lumber value chain. Note that not only did the mechanical properties improve in this study, but the volume per hectare also improved up to a spacing of $3.52 \mathrm{~m}$ due to higher site occupancy earlier in the rotation (Savill et al. 1997). This is despite the extra lumber recovered (Figs. 4c and 6c) for the widest spacing. The economic value of forest stands is thus not due solely to volume gains (Moore et al. 2018). Lumber graded to higher strength classes may therefore be possible without compromising on financial returns and may even improve it. It is recognized however that there will be several offsetting factors, i.e. higher establishment costs, lower sawmill volume recovery per log, harvesting costs of smaller diameter trees and transportation costs. Since there are less trees per hectare in wider spacing, it is likely that the number of boards with higher MOE will reduce not only in proportion but also in real numbers, reducing the sawmill's throughput of high stiffness products. Ultimately, a response from forest management will likely be initiated if a comprehensive economic evaluation of the value chain (including wood quality effects) can show similar or better returns than current management regimes. Initial work in South Africa shows promise in that regard (Charlton et al. 2020). Currently, many growers of saw logs are only 
charged per volume (Rais et al. 2014), but there is evidence that some sawmills are willing to pay a premium on raw material with improved wood properties (Hassegawa et al. 2020). Alternatively, it could be that a desire to incorporate lumber in demanding applications, with regard to structural performance, will eventually drive engineers to insist on an increase in mechanical properties (Moore 2012). Further pressure from local mills is also likely as the price of graded lumber reaches import parity (Crickmay and Associates 2013).

\section{Conclusion}

The advantages of closer spacing can be summarized as follows: first, at equivalent CA, mean WD and MFA are improved. Second, suppressed radial growth ensures that more mature rings are prevalent closer to the pith, further improving wood properties at similar distances from the pith. Third, lumber in the closer spacing will have better mean MFA and WD values. These advantages result in mechanical board properties improving with closer spacing. Moreover, the steep wood property gradients did not result in significantly increased lumber distortion.

Overall, it appears that if higher strength grades are desired then wide initial spacing is discouraged - at least within the context of short rotation systems. The underlying properties that control wood stiffness during juvenile growth may be improved with closer initial spacing before possible later thinning to reduce mortality and stimulate volume growth. Subsequent studies on P. patula should include further investigation into the mechanisms controlling MFA and WD. Future work is required on further understanding the development of annual wood properties, particularly WD and MFA, as well how they are affected by thinning. Economic evaluation of management regimes with closer spacing (over the full sawn value chain) including the positive effect of better lumber grades should be performed to better understand the potential of commercial implementation of such regimes.

Acknowledgements We appreciate the help of Wilmour Hendrikse, Ryan Charlton, Jacob Crous, Raphaela Hellmayr and Robert Evans with fieldwork, data preparation and laboratory measurements.

We also thank Alexis Achim and two anonymous reviewers for their constructive criticism.

The authors want to thank the Hans Merensky Foundation, Sappi South Africa, and Forestry South Africa for funding this work.

Data availability The datasets generated and/or analysed during the current study are available in the SUNScholarData repository (Erasmus et al. 2020), https://doi.org/10.25413/sun.12241268

\section{Compliance with ethical standards}

Conflicts of interest The authors declare that they have no conflict of interest.

\section{References}

Akaike H (1974) A New Look at the Statistical Model Identification. IEEE Trans Automat Contr 19:716-723

Amateis RL, Burkhart HE, Jeong GY (2013) Modulus of elasticity declines with decreasing planting density for loblolly pine (Pinus taeda) plantations. Ann For Sci 70:743-750. https://doi.org/10. 1007/s13595-013-0316-6

Ashton MS, Kelty MJ (2018) The Practice of Silviculture: Applied Forest Ecology. John Wiley \& Sons Ltd

Auty D, Gardiner BA, Achim A, Moore JR, Cameron AD (2013) Models for predicting microfibril angle variation in Scots pine. Ann For Sci 70:209-218. https://doi.org/10.1007/s13595-012-0248-6

Auty D, Moore J, Achim A, Lyon A, Mochan S, Gardiner B (2017) Effects of early respacing on the density and microfibril angle of Sitka spruce wood. Forestry 91:1-13. https://doi.org/10.1093/ forestry/cpx004

Biblis E (2006) Flexural properties and compliance to visual grade requirements of 2 by 4 and 2 by 6 loblolly pine lumber obtained from a 19-year-old plantation. For Prod J 56:71-73

Brazier JD, Mobbs I (1993) The influence of planting distance on structural wood yields of unthinned Sitka spruce. Forestry 66:332-352

Burdon RD, Paul Kibblewhite R, Walker JCF et al (2004) Juvenile versus mature wood: a new concept, orthogonal to corewood versus outerwood, with special reference to Pinus radiata and P. taeda. For Sci 50:399-415

Burdzik WMG (2004) Grade verification of SA pine - bending, modulus of rupture, modulus of elasticity, tension and compression. S Afr J 202:21-27. https://doi.org/10.1080/20702620.2004.10431786

Cameron AD (2002) Importance of early selective thinning in the development of long-term stability and improved log quality: a review. Forestry 75:25-35

Cave I, Walker J (1994) Stiffness of wood in fast-grown plantation softwoods: the influence of microfibril angle. For Prod J 44:43

CEN (2016) EN338:2016-07, Structural timber—strength classes. European Committee for Standardization, Brussels

Charlton RA, Naghizadeh Z, Ham C, Wessels CB (2020) Forest policy and economics A value chain comparison of Pinus patula sawlog management regimes based on different initial planting densities and effect on wood quality. For Policy Econ 111:11. https://doi.org/10. 1016/j.forpol.2019.102067

Clark AIII, Saucier JR, Baldwin VC, Bower DR (1994) Effect of initial spacing and thinning on lumber grade, yield, and strength of loblolly pine. For Prod J 44:14

Crickmay and Associates (2013) South African lumber index

Curtis RO (1982) A simple index of stand density for Douglas-fir. For Sci 28:92-94

DAFF (2017) Report on commercial timber resources and primary roundwood processing in South Africa.

Dahlen J, Jones PD, Seale RD, Shmulsky R (2012) Bending strength and stiffness of in-grade Douglas-fir and southern pine No. $22 \times 4$ lumber. Can J For Res 42:858-867. https://doi.org/10.1139/x2012041

Domec JC, Gartner BL (2002) Age- and position-related changes in hydraulic versus mechanical dysfunction of xylem: Inferring the design criteria for Douglas-fir wood structure. Tree Physiol 22:91104. https://doi.org/10.1093/treephys/22.2-3.91

Downes GM, Nyakuengama JG, Evans R et al (2002) Relationship between wood density, microfibril angle and stiffness in thinned and fertilized Pinus radiata. IAWA J 23:253-265. https://doi.org/10. 1163/22941932-90000302

Dowse GP, Wessels CB (2013) The structural grading of young South African grown Pinus patula sawn timber. South For a J For Sci 75: 37-41. https://doi.org/10.2989/20702620.2012.743768 
Erasmus J, Kunneke A, Drew DM, Wessels CB (2018) The effect of planting spacing on Pinus patula stem straightness, microfibril angle and wood density. Forestry: An International Journal of Forest Research 91:247-258. https://doi.org/10.1093/forestry/cpy005

Erasmus J, Wessels CB (2020) The effect of stand density management on Pinus patula lumber properties. Eur J For Res 139:247-257. https://doi.org/10.1007/s10342-019-01253-8

Erasmus J, Drew D, Wessels B (2020) Flexural properties of Pinus patula planted at different initial spacing. SUNScholarData [Dataset]. https://doi.org/10.25413/sun.12241268

Froneman GM, Wessels CB (2018) Increased planting density as a means for improving Pinus elliottii lumber stiffness. South J For Sci 80: 2620-2274. https://doi.org/10.2989/20702620.2017.1354282

Fujimoto T, Koga S (2010) An application of mixed-effects model to evaluate the effects of initial spacing on radial variation in wood density in Japanese larch (Larix kaempferi). J Wood Sci 56:7-14. https://doi.org/10.1007/s10086-009-1045-1

Gadow KV, Kotze H (2014) Tree survival and maximum density of planted forests - observations from South African spacing studies. For Ecosyst 1:9. https://doi.org/10.1186/s40663-014-0021-4

Godsmark R (2017) South African forestry and forest products industry 2016. Forestry South Africa

Green SR, Grace J, Hutchings NJ (1995) Observations of turbulent air flow in three stands of widely spaced Sitka spruce. Agric For Meteorol 1923:205-225

Harrington TB, Harrington CA, DeBell DS (2009) Effects of planting spacing and site quality on 25-year growth and mortality relationships of Douglas-fir (Pseudotsuga menziesii var. menziesii). For Ecol Manag 258:18-25. https://doi.org/10.1016/j.foreco.2009.03. 039

Hassegawa M, Savard M, Lenz PRN, Duchateau E, Gélinas N, Bousquet J, Achim A (2020) White spruce wood quality for lumber products: priority traits and their enhancement through tree improvement. Forestry 93:16-37. https://doi.org/10.1093/forestry/cpz050

Hein S, Mäkinen H, Yue C, Kohnle U (2007) Modelling branch characteristics of Norway spruce from wide spacings in Germany. For Ecol Manag 242:155-164. https://doi.org/10.1016/j.foreco.2007.01.014

Huang C-L, Lindström H, Nakada R, Ralston J (2003) Cell wall structure and wood properties determined by acoustics - a selective review. Holz Roh Werkst 61:321-335. https://doi.org/10.1007/s00107003-0398-1

Johansson C-J (2003) Grading of timber with respect to mechanical properties. Wiley, New York

Johansson K (1992) Effects of initial spacing on the stem and branch properties and graded quality of Picea abies (L.) Karst. Scand J For Res 7:503-514

Jordan L, Daniels RF, Clark A (2005) Multilevel nonlinear mixed-effects models for the modeling of earlywood and latewood microfibril angle. For Sci 51:357-371

Jürgensen C, Kollert W, Lebedys A (2014) Assessment of industrial roundwood production from planted forests. Planted Forests and Trees Working Papers (FAO) eng no. FP/48/E. Rome

Kotze H, du Toit B (2012) Silviculture of industrial pine plantations ins South Africa. In: Bredenkamp BV, Upfold S (eds) South African Forestry Handbook 5th. The Southern African Institute of Forestry

Krajnc L, Farrelly N, Harte AM (2019) The influence of crown and stem characteristics on timber quality in softwoods. For Ecol Manag 435: 8-17. https://doi.org/10.1016/j.foreco.2018.12.043

Kretschmann D, Bendtsen B (1992) Ultimate tensile stress and modulus of elasticity of fast-grown plantation loblolly pine lumber. Wood Fiber Sci 24:189-203

Kuprevicius A, Auty D, Achim A, Caspersen JP (2013) Quantifying the influence of live crown ratio on the mechanical properties of clear wood. Forestry 86:361-369. https://doi.org/10.1093/forestry/cpt006

Lachenbruch B, Moore J, Evans R (2011) Radial variation in wood structure and function in woody plants, and hypotheses for its occurrence.
In: Size- and age-related changes in tree structure and function. Springer, Dordrecht, pp 121-164

Larson PR, Kretschmann DE, Clark III A, Isebrands JG (2001) Formation and properties of juvenile wood in southern pines: a synopsis. Gen. Tech. Rep. FPL-GTR-129. US Department of Agriculture, Forest Service, Forest Products Laboratory, Madison, $42 \mathrm{p}$

Lindstrom MJ., Bates DM. (1990) Nonlinear mixed effects models for repeated measures. Biometrics 46:673-687. https://doi.org/10.2307/ 2532087

Louw WJA (2006) General history of the South African forest industry: 2003 to 2006. South African For J 208:79-88. https://doi.org/10. 2989/10295920609505264

Macdonald E, Hubert J (2002) A review of the effects of silviculture on timber quality of Sitka spruce. Forestry 75:107-138

Malan FS (2012) Solid wood properties and qualities of South African grown pine and eucalyptus species. In: Bredenkamp BV, Upfold SJ (eds) South African Forestry Handbook, 5th edn. South African Institute for Forestry, pp 621-673

Malan FS (2010) Corewood in South African pine: necessity and opportunities for improvement. South For J For Sci 72:99-105. https://doi. org/10.2989/20702620.2010.507032

Malan FS, Retief RJ, Male JR (1997) The influence of planting espacement on the wood density and pulping properties of Pinus patula. South African For J 180:23-32. https://doi.org/10.1080/ 10295925.1997.9631164

Milne R (1991) Dynamics of swaying of Picea sitchensis. Tree Physiol 9: 383-399. https://doi.org/10.1093/treephys/9.3.383

Moore J (2012) Growing fit-for-purpose structural timber what is the target and how do we get there? New Zeal J For 57:17-24

Moore J, Achim A, Lyon A, Mochan S, Gardiner B (2009) Effects of early re-spacing on the physical and mechanical properties of Sitka spruce structural timber. For Ecol Manag 258:1174-1180. https:// doi.org/10.1016/j.foreco.2009.06.009

Moore JR, Cown DJ (2017) Corewood (juvenile wood) and its impact on wood utilisation. Curr For Reports 3:107-118. https://doi.org/10. 1007/s40725-017-0055-2

Moore JR, Cown DJ, McKinley RB, Sabatia CO (2015) Effects of stand density and seedlot on three wood properties of young radiata pine grown at a dry-land site in New Zealand. New Zeal J For Sci 45:15. https://doi.org/10.1186/s40490-015-0035-x

Moore JR, Dash JP, Lee JR, McKinley RB, Dungey HS (2018) Quantifying the influence of seedlot and stand density on growth, wood properties and the economics of growing radiata pine. Forestry 91:327-340. https://doi.org/10.1093/forestry/cpx016

Muller BG, Louw JH, Malan FS (2017) Variation in selected solid wood properties of young Pinus patula from diverse sites in the Mpumalanga escarpment area in South Africa. South For 79:317327. https://doi.org/10.2989/00306525.2016.1255376

Pannell DJ (1997) Sensitivity analysis of normative economic models: theoretical framework and practical strategies. Agric Econ 16:139152. https://doi.org/10.1111/j.1574-0862.1997.tb00449.x

Parresol R (1999) Assessing tree and stand biomass: a review with examples and critical comparisons. For Sci 45:573-593

Pinheiro JC, Bates DM (2000) Mixed-effects models in S and S-PLUS. Springer

R Core Team (2018) R: A language and environment for statistical computing.

Rais A, Poschenrieder W, Pretzsch H, Van De Kuilen JWG (2014) Influence of initial plant density on sawn timber properties for Douglas-fir (Pseudotsuga menziesii (Mirb.) Franco). Ann For Sci 71:617-626. https://doi.org/10.1007/s13595-014-0362-8

SANS 10163-1 (2003) South African national standard. The structural use of timber Part 1: limit-states design

SANS 1783-1 (2018) South African national standard. Sawn softwood timber part 1: general requirements 
SANS 1783-2 (2013) South African national standard. Sawn softwood timber part 2: stress-graded structural timber and timber for frame wall construction

SANS 6122 (2014) South African national standard. Qualification testing of solid structural timber and laminated structural timber (glulam) for verifying timber grading systems in accordance to a given standard

Savill P, Evans J, Auclair D, Falck J (1997) Plantation silviculture in Europe. Oxford University Press, New York

Schimleck L, Antony F, Dahlen J, Moore J (2018) Wood and fiber quality of plantation-grown conifers: a summary of research with an emphasis on loblolly and Radiata pine. Forests 9. https://doi.org/10. 3390/ 9060298

Seifert T, Seifert S (2014) Modelling and simulation of tree biomass. In: Seifert T (ed) Bioenergy from wood: sustainable production in the Tropics. Springer, Dordrecht, pp 43-65

Sharma M, Amateis RL, Burkhart HE (2002) Top height definition and its effect on site index determination in thinned and unthinned loblolly pine plantations. For Ecol Manag 168:163-175. https://doi.org/ 10.1016/S0378-1127(01)00737-X

Spatz H, Bruechert F (2000) Basic biomechanics of self-supporting plants: wind loads and gravitational loads on a Norway spruce tree. For Ecol Manag 135:33-44

Tsoumis G (2009) Science and technology of wood: structure, properties, utilization

Vikram V, Cherry ML, Briggs D, Cress DW, Evans R, Howe GT (2011) Stiffness of Douglas-fir lumber: effects of wood properties and genetics. Can J For Res 41:1160-1173. https://doi.org/10.1139/x11039

Waghorn MJ, Watt MS (2013) Stand variation in Pinus radiata and its relationship with allometric scaling and critical buckling height. Ann Bot 111:675-680. https://doi.org/10.1093/aob/mct015

Walker JCF, Butterfield BG (1996) The importance of microfibril angle for the processing industries. New Zeal For 40:34-40

Walker JCF, Nakada R (1999) Understanding corewood in some softwoods: a selective review on stiffness and acoustics. Int For Rev 1: 251-259

Watt MS, Kirschbaum MUF (2011) Moving beyond simple linear allometric relationships between tree height and diameter. Ecol Model 222:3910-3916. https://doi.org/10.1016/j.ecolmodel.2011.10.011

Watt MS, Moore JR, Facon JP et al (2006) Modelling environmental variation in young's modulus for Pinus radiata and implications for determination of critical buckling height. Ann Bot 98:765-775. https://doi.org/10.1093/aob/mcl161

Watt MS, Zoric B, Kimberley MO, Harrington J (2011) Influence of stocking on radial and longitudinal variation in modulus of elasticity, microfibril angle, and density in a 24 -year-old Pinus radiata thinning trial. Can J For Res 41:1422-1431. https://doi.org/10. 1139/x11-070

Wessels BC, Froneman GM (2015) The potential for improving the stiffness of young South African grown Pinus radiata lumber by using high planting densities. Pro Lingo 11:58-64

Wessels CB, Dowse GP, Smit HC (2011) The flexural properties of young Pinus elliottii $\mathrm{x}$ Pinus caribaea var. hondurensis timber from the Southern Cape and their prediction from acoustic measurements. S J For Sci 73:137-147. https://doi.org/10.2989/20702620.2011. 640427

Wessels CB, Malan FS, Kidd M, Rypstra T (2015a) The variation of microfibril angle in South African grown Pinus patula and its influence on the stiffness of structural lumber. South For J For Sci 77: 213-219. https://doi.org/10.2989/20702620.2015.1031575

Wessels CB, Malan FS, Nel DG, Rypstra T (2014) Variation in strength, stiffness and related wood properties in young South African-grown Pinus patula. South For J For Sci 76:37-46. https://doi.org/10. 2989/20702620.2013.870406

Wessels CB, Malan FS, Seifert T, Louw JH, Rypstra T (2015b) The prediction of the flexural lumber properties from standing South African-grown Pinus patula trees. Eur J For Res 134:1-18. https://doi.org/10.1007/s10342-014-0829-z

West PW (2014) Growing Plantation Forests, 2nd edn. Springer

Xu P, Walker J (2004) Stiffness gradients in radiata pine trees. Wood Sci Technol 38:1-9

Zobel B, Buijtenen J Van (1894) Wood variation: its causes and control. Springer Verlag

Zobel B, Sprague JR (1998) Juvenile wood in forest trees. SpringerVerlag, Berlin Heidelberg

Zobel B, Talbert J (1984) Applied forest tree improvement. John Wiley \& Sons, New York

Zwolinski J, Bayley AD (2001) Research on planting stock and forest regeneration in South Africa. New For 22:59-74. https://doi.org/10. 1023/A:1012002229102

Publisher's note Springer Nature remains neutral with regard to jurisdictional claims in published maps and institutional affiliations. 